\title{
NATUREZA, DIREITO E JUSTIÇA - O FUNDAMENTO \\ DA LEI NATURAL NA NATUREZA HUMANA EM CÍCERO.
}

\author{
[NATURE, LAW AND JUSTICE - THE FOUNDATION OF \\ NATURAL LAW IN HUMAN NATURE IN CICERO.]
}

\section{Marcos Rohling ${ }^{1}$}

recebido: $07 / 2014$ aprovado: $12 / 2014$

RESUMO: Embora admirado como advogado e orador, Cícero não é reconhecido como um filósofo original. Seus textos e obras são vistos frequentemente como reproduções, em geral, de ideias estoicas, céticoacadêmicas e peripatéticas. A propósito da interpretação estóica que recorrentemente vem recebendo dos críticos e admiradores, propõe-se, nesse texto, uma interpretação da doutrina da lei natural de Cícero mais próxima do conceito aristotélico de natureza. Com isso, as críticas que sua teoria da lei natural recebeu, por estar mais próxima da concepção cosmológica estoica, seriam superadas e mais facilmente compreender-se-ia, no horizonte medieval, a importância de sua obra, sobretudo, para a teoria da lei natural de Tomás de Aquino. Discorre-se, do mesmo modo, sobre a conexão dessa concepção de lei natural com o direito e a justiça na dimensão da Re Publica.

PALAVRAS-CHAVES: Lei Natural, Direito, Natureza Humana, Justiça, Cícero.

ABSTRACT: Although admired as a lawyer and orator, Cicero is not recognized as an original philosopher. His texts and works are often seen as reproductions, in general, of Stoic ideas, skeptical academic and peripatetic. The purpose of the Stoic interpretation that recurrently been receiving from critics and admirers, it is proposed in this paper to an interpretation of the

\footnotetext{
${ }^{1}$ Graduado em Filosofia (UFSC), graduando em Direito (UNISUL), mestre em Ética e Filosofia Política (UFSC), doutorando em Educação (UFSC) e professor da rede de ensino do estado de Santa Catarina. Lattes: http://lattes.cnpq.br/1426156565430729. $\quad$ E-mail: marcos_roh@yahoo.com.br.
} 
doctrine of natural law of Cicero closer to the Aristotelian concept of nature. Thus, the criticism that his theory of natural law received by being closer to the Stoic cosmological conception, would be overcome more easily understand and would, in medieval horizon, the importance of his work, especially to the theory of law natural Aquinas. It discourses, likewise, about the connection of this conception of natural law with the law and justice in the dimension of Re Publica.

Keywords: Natural Law, Law, Human Nature, Justice, Cicero.

\section{Introdução}

Os últimos séculos viram, de muitos modos, muitas críticas à teoria da lei natural como fundamento da teoria do direito, da ética e da política. Ao final daquilo que, em história, chama-se idade média, com Grócio, o jusnaturalismo verteu-se para um tom racionalista, rejeitando as dimensões da cosmologia estóica e cristã-aristotélica, predominantes na concepção de mundo da antiguidade. Após Kant, com Hegel, o jusnaturalismo foi alvejado viceralmente e, ao mesmo tempo, viu-se erigir o positivismo jurídico o qual com Austin, Kelsen e Hart tornou-se uma doutrina respeitável no âmbito da fundamentação do direito. De fato, o positivismo jurídico tornou-se uma doutrina considerável e extraordinária como fundamento e justificação do direito, de tal modo a constituir-se no principal referencial e adversário de doutrinas contemporâneas, como o interpretativismo jurídico, de Dworkin.

Contudo, o jusnaturalismo ressurgiu, de forma consistente, no cenário intelectual jurídico e vem alcançando certo respeito, tal como apresentado por pensadores como Finnis, George e Grisez. Essa nova doutrina, rejeita aspectos identitários da configuração conceitual que tinha na antiguidade e, de certo 
modo, aceita muitas das críticas desenvolvidas por doutrinas como a do positivismo jurídico. Na verdade, a formulação dessa nova teoria da lei natural, como encontrada em Finnis, conjuga o positivismo jurídico com o jusnaturalismo com o propósito de ser a melhor teoria descritiva dos critérios de validade do direito.

O presente texto tem por fito lançar luz a discussão do jusnaturalismo tal como encontra-se na obra de Cícero, no sentido de se discutir as bases do seu pensamento no que concerne à relação entre lei natural, natureza humana e direito. Em geral, afirma-se que Cícero não apresentou uma teoria genuína e original. Essa posição, todavia, é controversa, porque, na verdade, as obras de Cícero representam mais adequadamente uma tentativa autêntica de convidar o leitor a julgar a perspectiva, a visão mais plausível. ${ }^{2}$ Mas, mais do que isso, defender-se-á que o pensamento do autor estabelece inovadoramente, à luz da teoria aristotélica, a noção de que o direito natural não é procedente prioritariamente de uma cosmologia estóica, mas, antes, de uma concepção aristotélica da natureza humana. Sendo assim, o artigo abordará (1) o renascimento da teoria do direito natural, que recentemente tem instado à reflexão no âmbito da filosofia e da teoria do direito, (2) do mesmo que uma defesa aristotélica da concepção jusnaturalista, tal como encontrada em Cícero, (3) bem como uma discussão da justiça e sua relação com o direito, do qual apresentam-se alguns conceitos relevantes. ${ }^{3}$

${ }^{2}$ Cf. PAWELL, Introduction: Cicero's Philosophical Works and Their Backgraund, p. 30. In: PAWELL, Cicero, The Philosopher - Twelve Papers. Oxford: Clarenton Press, 1999.

${ }^{3}$ E patente afirmar que as ideias contidas nesse texto foram inspiradas em SEAGRAVE, Cicero, Aquinas, and Contemporary Issues in Natural Law ÁGORA FILOSÓFICA .v. 1. n. 2 (2014), pp.144-189 e-ISSN 1982-999x 
Um renomado historiador da filosofia política e da filosofia do direito, Guido Fassò, em sua História de la Filosofia del Derecho, afirmou que Cícero foi genuinamente o primeiro filósofo do direito, e que seu De Legibus constitui originalmente a primeira e verdadeira obra de filosofia do direito na história do pensamento de matiz ocidental. ${ }^{4}$ De fato, embora não tenha sido tão original no campo da filosofia, foi inquestionavelmente relevante para a cultura ocidental, seja pelo papel mediador no que concerne à transmissão da filosofia grega para a cultura romana, seja pela contribuição ímpar ao direito, sobretudo no que se refere à sistematização, à criação de conceitos e à prática forense. Assim, centrando a reflexão em De Legibus ${ }^{5}$, De Re Publica $^{6}$, De Offiiciis ${ }^{7}$, principalmente, espera-se que as ideias apresentadas sejam tais que ofereçam elementos que possam alimentar a superação da convencional interpretação estoica da

Theory, The Review of Metaphysics, vol. 62, No. 3, March, 2009. Nos pontos essenciais, consideram-se corretas e acertadas as suas interpretações.

${ }^{4}$ FASSÒ, História de la Filosofia del Derecho - Antiguidad y Edad Media, 96.

5 CÍCERO, De Legibus. Disponível em: http://www.thelatinlibrary.com/cicero/leg.shtml, acessado em 14/12/2012. Foram usadas as seguintes traduções: Las Leyes, traducción, introducción y notas por A. D’Ors, Madrid: Instituto de Estudios Políticos, 1953; Das Leis, introdução, tradução e notas por Marino Kury, Caxias do Sul: Educs, 2004. Em geral, usa-se a tradução em língua portuguesa para as citações por meio de $D L$.

6 CÍCERO, De Re Publica. Disponível em: http://www.thelatinlibrary.com/cicero/repub.shtml, acessado em 14/12/2012. Foram usadas as seguintes traduções: Da Republica, tradução e notas por Amador Cisneiro, $2^{a}$ Ed., São Paulo: Edipro, 2011; Da Republica, (Coleção Os Pensadores), tradução Amador Cisneiro, São Paulo: Abril Cultural, 1985. Em geral, usa-se a tradução ofertada pela Edipro para as citações em português.

CÍCERO, De Officiis. Disponível em: http://www.thelatinlibrary.com/cicero/off.shtml, acessado em 14/12/12. Foi usada a seguinte tradução: Dos Deveres, tradução, introdução, notas, índice e lossário por Carlos Humberto Gomes. Lisboa: Edições 70, 2000, para as citações no vernáculo. 
doutrina da lei natural encotrada em Cícero no que diz respeito à sua fundamentação.

\section{O Renascimento da Teoria do Direito Natural}

$\mathrm{O}$ advento da nova teoria do direito natural, em meados do século $\mathrm{XX}$, teve o mérito de recepcionar o pensamento de Tomás de Aquino (e com ele, a tradição que o precede) no seio da filosofia analítica e na discussão contemporânea nos âmbitos do direito, da moral e da política. ${ }^{8}$ E, como sugere Seagreve, com Finnis o Aquinate viu sua obra tornar-se fundamental em relação aos direitos naturais que definem a tradição liberal ${ }^{9}$, tese com a qual certamente um autor como Villey não concordaria. ${ }^{10}$

A razão para tal é que essa teoria é, em grande medida, desenraizada de sua base clássica. Essa mudança resulta significativa, pois a lei natural tomista, e com ela a ciceroniana, torna-se mais persuasiva, e não menos, quando é vista à luz de

\footnotetext{
${ }^{8}$ ROHLING, Lei Natural e Direito. A Crítica de Finnis ao Positivismo Jurídico, 159-61.

${ }^{9}$ SEAGRAVE, Cicero, Aquinas, and Contemporary Issues in Natural Law Theory. The Review of Metaphysics, vol. 62, No. 3, March, 2009.

${ }^{10}$ É grandemente conhecido que Villey defende a tese de que o direito subjetivo, identificado com a modernidade por conta do nominalismo, tem sua origem nos pensadores medievais, entre os quais, dá importância ímpar para Ockham. Os direitos liberais, que são direitos subjetivos, teriam assim as bases conceituais lançadas por autores posteriores a Tomás. Cf. VILLEY, $A$ Formação do Pensamento Jurídico Moderno, 221-88. Ocorre que a interpretação de Villey recebe críticas. Numa delas, no artigo Direito Subjetivo e Propriedade. Sobre o Tomismo de Villey, Storck defende que a ideia de que o germe do direito, em sentido subjetivo, é encontrado mesmo em autores anteriores a Ockham, como Godofredo de Fontaines, e que, inclusive na obra de Tomás, é possível encontrar alguns elementos incipientes do direito subjetivo, como, exempli gratia, na questão do dízimo. Cf. STORCK, Direito Subjetivo e Propriedade. Sobre o Tomismo de Villey, 57-65.
}

ÁGORA FILOSÓFICA

$$
\text { .v. 1. n. } 2 \text { (2014), pp.144-189 e-ISSN 1982-999x }
$$


sua fundação clássica. ${ }^{11}$ Nessa tradição, pode-se pontuar o nome de Aristóteles como o marco inicial, alguns ainda acenam para Platão, e Cícero como o grande intérprete antes de Tomás de Aquino. $^{12}$

À luz disso, parece que o debate entre defensores e opositores da lei natural contemporaneamente está, de fato, caracterizado por alguns pontos fundamentais de acordo:

i) A questão crucial da existência da lei natural tem sido amplamente rejeitada e substituída por, no âmbito da filosofia contemporânea, por algumas do seguinte tipo: algo como a lei natural existe?; há um padrão natural e objetivo para a ação humana?; certas idéias associadas à lei natural podem ser benéficas ou úteis num contexto liberal contemporâneo?;

ii) Como consequência, a busca pela lei natural em sentido estrito foi praticamente abandonada, de tal modo que a lei natural tornou-se uma mera expressão aristotélicocristã, enfraquecida pela força da investigação analítica moderna.

Uma vez que esse seja o contexto teórico contemporâneo das discussões em torno da lei natural, pretende-se sugerir com esse texto, na linha da questão da existência de uma lei natural, em sentido estrito, uma interpretação desta em Cícero como continuidade da abordagem aristotélica da natureza humana, de tal forma a considerar-se o papel ativo e distintivo que teve o autor na formação da tradição do direito natural. Assim, em

${ }^{11}$ SEAGRAVE, Cicero, Aquinas, and Contemporary Issues in Natural Law Theory. The Review of Metaphysics, vol. 62, No. 3, March, 2009.

${ }^{12}$ No vernáculo, o livro Direito Natural em Platão, de Lacerda, é um esforço teórico, exitoso, pode-se dizer, de estender as raízes do jusnaturalismo a Platão. Essa tese é encontrada igualmente em JAEGER, Alabanza de la Ley. Los Orígenes de la Filosofía Del Derecho y los Griegos. Madrid: Instituto de Estudíos Políticos, 1953. Contudo, esforços teóricos como LA TORRE, A. Sanches de. Los Griegos y el Derecho Natural. Madrid: Editorial Tecnos, 1962; e PIZZORNI, Reginaldo. Il Diritto Naturale - dalle origini a S Tomamaso d'Aquino. Bologna: Edizioni Studio Domenicano, 2000, incluindo o de Jaeger, remontam para os pré-socráticos os antecedentes jusnaturalistas. 
oposição às interpretações mais ortodoxas, isto é, mais aceitas da obra do Arpinate, compreende-se que a sua teorização do direito natural não é mera transmissão da elaboração estoicas, ou mesmo de suas ideias. ${ }^{13}$ Com isso, não se quer dizer que Cícero, de fato, não tenha se baseado nas ideias estoicas. Quer se dizer, antes, por meio de análise atenta e cuidadosa da teoria do direito natural, Cícero revela uma afinidade muito mais próxima da filosofia moral de Aristóteles do que do estoicismo. Corrobora essa ideia a afirmação de Nicgorski segunda a qual Platão, jutamente com Sócrates, Aristóteles e Carnéades uma das mais importantes fontes e recursos filosóficos de Cícero. ${ }^{14}$ Esse entendimento calcado na tradição que remonta à Aristóteles constituirá a base para a explanação do papel que tem a lei natural no direito e na moral em Cícero numa tradição que terá Tomás de Aquino como grande expoente.

\section{Cícero e a Lei Natural}

A história do pensamento Ocidental é testemunha da valorização que Cícero recebeu, sobretudo no campo da retórica, no qual suas conquistas sempre foram reconhecidas. Nas últimas décadas apenas é que sua reputação, como filósofo político e moral, voltou a ter o reconhecimento gozado na Idade média. ${ }^{15}$ Apesar da renovada atenção, contudo, a teoria da lei natural formulada por ele ainda é considerada, em grande parte, como

\footnotetext{
13 Entre esses autores, que pertencem à interpretação denominada de ortodoxa, encontram-se Weinreb, Strauss, Holton, Horsley e Wolfe.

${ }^{14}$ NICGORSKI, Cicero and the Rebirth of Political Philosophy, 71.

${ }_{15}$ NICGORSKI, Cicero and the Rebirth of Political Philosophy, 63-65.

ÁGORA FILOSÓFICA .v. 1.n. 2 (2014), pp.144-189 e-ISSN 1982-999x
} 
carecendo de originalidade e tendo fortes traços estoicos, de tal forma a apenas repetir ideias de pensadores estoicos.

Caracterizada desse modo, a lei natural de Cícero estaria gravemente exposta a uma série de dificuldades. A principal delas envolveria a cosmologia estóica, a qual constitui a base para a sua teoria da lei natural e que ele mesmo já havia desacreditado em seu De Natura Deorum, razão pela qual, desde então, ela tem sido amplamente rechaçada. Algumas críticas, de fato, interpõem-se a elaboração de Cícero da lei natural, entendida como extensão das considerações estoicas. Entre essas, tem-se a de que mesmo quando a caracterização estoica da lei natural ciceroniana não é aceita em sua forma precisa, tal concepção pode ser considerada, no máximo, como um estoicismo moderado e transformado. ${ }^{16}$ Um elemento interessante é o de que a plausibilidade dessa caracterização decorre da aparente relutância, da parte de Cícero, de falar em voz própria nos seus diálogos e escritos. Como é evidente, no De Re Publica, o Arpinate fala apenas prefaciando, deixando o diálogo principalmente para Cipião, Lélio e Filão.

Embora se possa seguir a interpretação acima, é curioso perceber o que Cícero tem em mente. No De Legibus, o autor claramente indica que está seguindo o padrão estabelecido por Platão, no plano geral da obra (embora ele próprio apareça como principal interlocutor), dedicando diálogos separados, mas interrelacionados: i) à República; e ii) às sua leis. ${ }^{17}$ Platão, é verdade, é frequentemente presente na obra de Cícero; tanto é

16 HORSLEY, The Law of Nature in Philo and Cicero, 58. Apud. SEAGRAVE, Cicero, Aquinas, and Contemporary Issues in Natural Law Theory. The Review of Metaphysics, vol. 62, No. 3, March, 2009.

${ }^{17}$ CÍCERO, DL I, 5, 15, p. 46. 
que, em sua apresentação de A República, de Platão, ao remeterse justamente ao De Republica e ao De Legibus, do Arpinate, a autora afirma o desejo que Cícero tinha de imitar a Platão. ${ }^{18}$

No primeiro livro do De Legibus, no entanto, Cícero afirma que está seguindo o método dos filósofos que construíram oficinas para a produção da sabedoria, os estóicos. Como afirma Seagreve, Cícero é lúcido quanto à opinião alheia sobre ele mesmo, pois Ático, no De Legibus, antecipa a forma com a qual Cícero será conhecido na história ao acusá-lo de ser o tipo de homem que não segue seu próprio juízo num debate. Todavia, é interessante observar a breve resposta de Cícero, constituindo um alerta aos leitores e intérpretes: "non semper!". ${ }^{19}$ Ora, nos seus escritos, Cícero está preocupado não apenas com a apresentação de seus próprios pontos de vistas, mas principalmente com a avaliação crítica das perspectivas dos epicuristas, dos estoicos e dos peripatéticos. Sendo assim, Cícero intercambia posições conceituais: para refutar os epicuristas, toma posição, em grande parte, dos estoicos; para refutar os estoicos, por sua vez, adota a perspectiva dos peripatéticos; e, finalmente, para refutar os peripatéticos, retoma a posição dos estoicos.

No De Officiis, há elementos que permitem compreender mais bem essa característica do método de Cícero. Essa obra,

\footnotetext{
${ }^{18}$ Rocha Pereira, remetendo-se ao De Re Publica, afirma que o Sonho de Cipião constituía uma réplica ao mito de Er e que a escolha de Cipião e de Cipião, o Africano, é significativa, pois, com estas figuras, está-se no ponto de intersecção entre a virtus romana e a sophia grega. Como afirma, inspirado no modelo de Platão, Cícero descreveu uma cidade que é uma idealização de Roma e que, esta, por sua vez, servirá de modelo ao principado de Augusto. Cf. ROCHA PEREIRA, Introdução, L-LI. In. PLATÃO, A República.

${ }^{19}$ CÍCERO, DL I, 13, p. 54.

ÁGORA FILOSÓFICA .v. 1. n. 2 (2014), pp.144-189 e-ISSN 1982-999x
} 
como é seu costume, tem um destinatário particular, a saber, seu filho e, como é evidente, claramente aponta para o seguimento do estoicismo no conjunto geral das ideias, mormente aquele de Panécio. Explicando a forma adequada de interpretação dessa obra, Cícero afirma:

Seguimos, então, por agora e neste domínio, os
Estóicos principalmente, não como interpretes,
mas antes, como é nosso costume, já que
poderemos auferir a partir das suas fontes, de
acordo com a nossa escolha e julgamento, o
quanto de alguma maneira parecer ser
suficiente. $^{20}$

O modo, portanto, como se apropria ou usa as idéias das escolas - nesse caso, dos estóicos - envolve o exercício de descrição e discernimento de uma forma que sirva aos seus propósitos, no sentido de discussão e debate acerca de um determinado tema. Retomando a resposta a Ático, no De Legibus, observa-se que Cícero esclarece que a sua posição "Non Semper!" não significaria que siga os outros de forma irrefletida e que ocasionalmente traga sua própria compreensão à baila, mas que certamente repete somente as opiniões alheias quando elas são relevantes para o propósito de sua exposição. Sendo é assim, é certo que Cícero vale-se dos seus personagens para articular diferentes opiniões na direção de uma discussão substancial e significativa para a qual cada um dos personagens é, de todo, relevante. ${ }^{21}$

À luz de afirmações como essas e outras, com igual teor ${ }^{22}$, muitos teóricos e comentaristas contemporâneos têm rejeitado a

\footnotetext{
${ }^{20}$ CÍCERO, De Officiis I, 6. No Oringinal: "Sequemur igitur hoc quidem tempore et hac in quaestione potissimum Stoicos, non ut interpretes, sed, ut solemus, e fontibus eorum iudicio arbitrioque nostro quantum quoque modo videbitur, hauriemus."

${ }^{21}$ CÍCERO, DL I, 13, p. 54.

${ }^{22}$ De Officiis I, 6; De Finibus Bonorum et Malorum. ÁGORA FILOSÓFICA .v. 1. n. 2 (2014), pp.144-189 e-ISSN 1982-999x
} 
posição simplista e reducionista segundo a qual as declarações de Cícero a respeito da lei natural são apenas uma regurgitação irrefletida de princípios estóicos. ${ }^{23}$ Todavia, à pergunta de se o propósito de Cícero era o de apresentar uma doutrina do direito natural, em sentido estrito, esses intérpretes frequentemente respondem de forma negativa, destacando-se duas formas básicas de respostas, assim sumarizadas por Seagrave ${ }^{24}$ :

i) A primeira dessas respostas reflete a ideia do médioplatonismo, inicialmente defendida por Antíoco de Ascalão, de acordo com o qual havia um 'Deus transcendente' que fora legislador do mesmo modo que Pai e Criador do mundo. Ora, se um Deus transcendente é a fonte imediata dessa lei natural, essa lei não se qualifica estritamente como natural, pois que uma tal lei seria devidamente chamada de divina e apenas secundária ou metaforicamente natural. De acordo com essa interpretação, vale dizer, da lei natural como direito divino. Cícero teria antecipado a absorção da lei natural pela teologia, o que supostamente ocorre na Idade Média cristã. Contudo, se a lei natural tal como a caracteriza Cícero é uma lei divina, então ela não é natural no sentido próprio de inerência à natureza e, nesse sentido, a próprio propósito de Cícero não seria apresentar uma teoria da lei natural, mas, antes, substituir a lei natural imanente estóica por uma transcendentalmente divina, eterna.

ii) A segunda dessas respostas segue, de certo modo, a conclusão da primeira. Na perspectiva de Strauss e outros ligados a ele, como Holton, o propósito de Cícero era o de apresentar a lei natural estóica de uma forma que revelasse a própria incoerência dessa

${ }^{23}$ Entre esses teóricos, notadamente, encontram-se STRAUSS, Leo. Direito Natural e História. Lisboa: Edições 70, 2009; NICGORSKI, Walter. Cicero's Paradoxes and His Idea of Utility. Political Theory, 12, 557-578, Nov., 1984; HORSLEY, Richard A. The Law of Nature in Philo and Cicero. The Harvard Theological Review, 71, 35-59, January-April, 1978; HOLTON, James E. Marco Túlio Cicerón. In: Historia de la Filosofía Política, 158-176; CROSSON, Frederick. Religion and Natural Law. American Journal of Jurisprudence, 33, 1-17, 1988; e ARKES, Hadley. That 'Nature Herself Has Placed in Our Ears a Power of Judging:' Some Reflections on the 'Naturalism' of Cicero. In: Natural Law Theory: Contemporary Essays, 245-277.

${ }^{24}$ SEAGRAVE, Cicero, Aquinas, and Contemporary Issues in Natural Law Theory. The Review of Metaphysics, vol. 62, No. 3, March, 2009.

ÁGORA FILOSÓFICA .v. 1. n. 2 (2014), pp.144-189 e-ISSN 1982-999x 
lei natural bem como sua incompatibilidade com a doutrina mais aceitável do direito natural. Trata-se de uma interpretação de Cícero á luz de uma crítica específica da teoria da lei natural, a saber, que representa incoerente interseção do direito natural e de alguma forma de lei divina e eterna. Nesse sentido, percebendo Cícero que noção de direito natural não pode ser significativamente diferente daquela da lei eterna e ainda que os assuntos humanos não admitem regras categóricas, mas, em vez disso, têm de ser guiados pela norma do direito natural, sutilmente rejeita suas declarações superficiais acerca dessa lei natural.

Ora, convém questionar se Cícero, de facto, como faz Seagrave, tinha por propósito apresentar claramente um ensinamento autêntico e coerente a respeito da lei natural. $\mathrm{Na}$ realização desse questionamento, argumentar-se-á que, através dos diferentes contextos nos quais as declarações de Cícero sobre a lei natural aparecem, emerge uma continuidade subjacente, enraizada na perspectiva aristotélica da natureza, que aparecerá, igualmente, em Tomás de Aquino. Esse entendimento é desenvolvido de tal maneira que a lei natural é percebida como necessariamente inerente à natureza humana e encerrada na sua própria descrição. $\mathrm{O}$ direito, por consequência, encontraria seu fundamento na própria natureza humana, na recta ratio, de tal forma que as normas que estabeleceria seriam, portanto, extensões de necessidades humanas, porque enraizada na natureza. ${ }^{25}$

Nesse sentido, urge adentrar o pensamento de Cícero, notadamente suas afirmações acerca da lei natural, com o fito de, através dessas afirmações, afirmar a sua plausibilidade de uma interpretação mais próxima de Aristóteles do que dos estoicos ou qualquer outra escola. A primeira dessas passagens,

\footnotetext{
${ }^{25}$ SEAGRAVE, Cicero, Aquinas, and Contemporary Issues in Natural Law Theory. The Review of Metaphysics, vol. 62, No. 3, March, 2009.

ÁGORA FILOSÓFICA .v. 1.n. 2 (2014), pp.144-189 e-ISSN 1982-999x
} 
a mais citada nos escritos de Cícero quanto à lei natural, é dada por Lélio, no terceiro livro de De Re Publica.

A razão reta, conforme à natureza, gravada em todos os corações, imutável, eterna, cuja voz ensina e prescreve o bem, afasta do mal que proíbe e, ora com seus mandados, ora com suas proibições, jamais se dirige inutilmente aos bons, nem fica impotente ante os maus. Essa lei não pode ser contestada, nem derrogada em parte, nem anulada; não podemos ser isentos de seu cumprimento pelo povo nem pelo Senado; não há que procurar para ela outro comentador nem intérprete; não é uma lei em Roma e outra em Atenas, uma antes e outra depois, mas uma, sempiterna e imutável, entre todos os povos e em todos os tempos; uno será sempre o seu imperador e mestre, que é Deus, seu inventor, sancionador e publicador, não podendo o homem desconhecê-la sem renegar-se a si mesmo, sem despojar-se do seu caráter humano e sem atrair sobre si a mais cruel expiação, embora tenha conseguido evitar todos os outros suplícios. ${ }^{26}$

Em resposta ao ataque de Filão à base da lei natural, como é evidente, Lélio afirma que a verdadeira lei é a reta razão, a recta ratio, de acordo com a natureza, a qual, por sua vez, é imutável e eterna e de aplicação universal, que chama ao dever por seus comandos e evita irregularidades por meio de suas proibições. Conforme se observa, apesar da primeira parte da citação enfatizar o aspecto natural da lei como verdadeira lei, a

${ }^{26}$ CÍCERO, De Re Publica, III, XVII, 87-8. No original: "Est quidem vera lex recta ratio naturae congruens, diffusa in omnes, constans, sempiterna, quae vocet ad officium iubendo, vetando a fraude detterreat; quae tamen neque probos frustra iubet aut vetat, nec improbos iubendo aut vetando movet. Huic legi nec obrogari fas est neque derogari aliquid ex hac licet neque tota abrogari potest, nec vero aut per senatum aut per populum solvi hac lege possumus, neque est quaerendus explanator aut interpres eius alius, nec erit alia lex Romae, alia Athenis, alia nunc, alia posthac, sed et omnes gentes et omni tempore una lex et sempiterna et immutabilis continebit, unusque erit communis quase magister et imperator omnium deus, ille legis huius inventor, disceptator, lator; cui qui non parebit, ipse se fugiet ac naturam hominis aspernatus hoc ipso luet máximas poenas, etiamsi cetera supplicia, quae putantur, effugerit."

ÁGORA FILOSÓFICA

.v. 1.n. 2 (2014), pp.144-189 e-ISSN 1982-999x 
segunda metade da exposição introduz alguns elementos de ambigüidade, a saber, faz menção à lei eterna e a seu promulgador e intérprete, isto é, Deus. Ora, quem é desobediente está fugindo de si mesmo e negando sua natureza humana. Em função desse fato, ele sofrerá as piores penas, mesmo se escapar ao que se considera comumente castigo. Contudo, a menção a Deus como autor, promulgador e juiz de execução da lei verdadeira parece estabelecer esta lei como um bem divino.

As afirmações acerca de Deus parecem constituir um problema em relação às afirmações feitas por Cícero, no que respeita à lei natural, pois, como pontua Seagrave ${ }^{27}$ : i) os homens não precisam olhar para fora de si mesmos para descobrir a verdadeira lei; e ii) contestar essa lei não é simplesmente desobedecer ao próprio Deus, mas negar a própria natureza humana, que inclui seu próprio mecanismo adequado e eficaz de aplicação. Ora, realmente há uma contradição gritante, pois a lei natural, numa direção parece mais encontrar-se enraizada na natureza humana e, noutra direção, parece ser a expressão mais evidente da vontade divina.

Além disso, poder-se-ia, igualmente, como faz Seagrave, estabelecer outra forma de questionamento, qual seja, a de indagar se essa era realmente a posição de Cícero, haja vista, no diálogo, a declaração em análise ter sido feita por Lélio, em vez de Cipião ou mesmo, pelo próprio Cícero. ${ }^{28}$ Tendo essa questão em mente, as evidências textuais corroboram a afirmação de que

\footnotetext{
27 SEAGRAVE, Cicero, Aquinas, and Contemporary Issues in Natural Law Theory. The Review of Metaphysics, vol. 62, No. 3, March, 2009.

${ }^{28}$ SEAGRAVE, Cicero, Aquinas, and Contemporary Issues in Natural Law Theory. The Review of Metaphysics, vol. 62, No. 3, March, 2009.

ÁGORA FILOSÓFICA .v. 1. n. 2 (2014), pp.144-189 e-ISSN 1982-999x
} 
o conteúdo da afirmação é a posição de Cícero, pois, em rara pausa no diálogo, Cícero - o narrador do De Re Publica descreve a recepção das observações feitas por Lélio entre seus interlocutores, de tal modo que indica a satisfação dos interpeladores com as suas observações, notadamente Cipião quase foi levado ao êxtase. ${ }^{29}$

Há algumas razões, então, as quais podem ser mais claramente enunciadas para defender a ideia de que essa passagem, de algum modo, trata da opinião de Cícero. Sendo assim, em primeiro lugar, essa passagem mitiga grandemente as dificuldades interpretativas associadas às opiniões no decurso do diálogo e, em particular, do próprio Cícero, porque ele mesmo, que costumeiramente se expressa por meio de Cipião, manifesta de tal forma o comportamento extasiado e entusiasta deste com as observações de Lélio. Em segundo lugar, é claro e evidente que Cícero leva realmente a sério a declaração de Lélio, considerando-a como sua, porque interrompe momentaneamente o fluxo do diálogo para inserir sua própria voz. Uma terceira razão auferida é que, ao argumentar contra os epicuristas em sua própria voz, no De Finibus, Cícero cita, com aprovação, o discurso de Lélio, no De Re Publica. ${ }^{30}$ Reforçando essa afirmação, também falando em sua voz própria, no primeiro livro, do De Legibus, Cícero está principalmente preocupado com o oferecimento de argumentos adicionais para apoiar a posição de Lélio de que a justiça e a lei estão enraizadas na natureza. $^{31}$ A origem divina do homem impõe a ele uma

\footnotetext{
${ }^{29}$ CÍCERO, De Re Publica, III.

${ }^{30}$ CÍCERO, De Finibus Bonorum et Malorum, II, 59.

${ }^{31}$ CÍCERO, DL I, 13, p. 54. 
comunidade natural de direito, de tal forma que este se funda na mesma natureza humana, e que será aquela descrita no $D e R e$ Publica. ${ }^{32}$ Assim, lê-se:

Tens razão, retamente falas. Porém, há que seguir o método dos filósofos, não me refiro aos antigos, mas aos que - abrindo escolas de sabedoria - costumam expor em análises distintas, tópico por tópico, matérias que antes eram com plena liberdade discutidas. Já não se acredita que um tema como o nosso possa esgotar-se sem estabelecer previamente, por discussão separada, que a natureza é a fonte do direito. $^{33}$

Sendo esse o caso, pode-se dizer que, enquanto as evidências textuais não demonstram uma identificação incondicional de Cícero com as declarações de Lélio a respeito da lei natural, ela, por sua vez, indica que tais declarações, longe de serem sutilmente rejeitadas, estão, em grande parte, consonantes com as suas próprias opiniões acerca da matéria. De modo que a natureza humana seja, ela mesma, o fundamento do direito. A partir disso, cabe, por agora, mostrar como a posição de Lélio pode ser separada e refletida na de Cícero. Isso pode ser visto considerando-se o nível de correspondência entre a descrição de Lélio e aquelas resultantes das formulações da lei natural que aparecem noutros lugares da obra de Cícero.

Se o propósito é o diagnóstico do nível de correspondência entre a descrição de Lélio de verdadeira lei (vera lex) e as formulações que aparecem em diversos lugares dos escritos de

\footnotetext{
${ }^{32}$ D’ORS, nota 163, In: CICERÓN, Las Leyes, 82.

${ }^{33}$ CÍCERO, DL I, 13, p. 54. No Original: "Recte dicis, et res se sic habet. Verum philosophorum more, non ueterum quidem illorum, sed eorum qui quasi officinas instruxerunt sapientiae, quae fuse olim disputabantur ac libere, ea nunc articulatim distincta dicuntur. Nec enim satis fieri censent huic loco qui nunc est in manibus, nisi separatim hoc ipsum, <a> natura esse ius, disputarint." 
Cícero, então, as formulações, tais como, lei da natureza ${ }^{34}$, lei universal $^{35}$, lei suprema ${ }^{36}$ e direito das gentes $^{37}$, devem ser especialmente consideradas. No primeiro livro do De Legibus cada uma dessas alternativas surge e se entrelaça através da discussão iniciada por Cícero. Nesse contexto, o autor expressa a opinião dos homens mais instruídos os quais definem o direito como a razão maior, implantada na natureza, que comanda o que deve ser feito e proíbe o contrário. Esta razão é a lei quando firmemente fixada e totalmente desenvolvida. ${ }^{38}$ Esta declaração que, aos olhos de Cícero, parece correta ${ }^{39}$, conecta o direito com a razão e a natureza humana, os quais formam os princípios da verdadeira lei na descrição de Lélio.

Notadamente, após essa definição, Cícero também vincula a razão superior com a noção de recta ratio $^{40}$, afirmada por Lélio, e introduz uma ambiguidade semelhante ao referir-se ao Deus transcendente que governa a comunidade de deuses e de homens. $^{41}$ No desenvolvimento da descrição de Lélio da verdadeira lei, Cícero indica que as várias formulações mencionadas acima se referem à mesma lei analisada, tendo em consideração diversas relações. Essa lei, com o fito de distinguila da multidão de leis, isto é, de decretos escritos e afins que são estabelecidos por seres humanos para lidar com questões menores, é tida como verdadeira e suprema. ${ }^{42}$ Essa descrição da

\footnotetext{
${ }^{34}$ CÍCERO, De Officiis III, 69; DL I, 4, p. 44-5.

${ }^{35}$ CÍCERO, DL I, 4, p. 45; 5, p.47.

${ }^{36}$ CÍCERO, DL I, 6, p. 48.

${ }^{37}$ CÍCERO, De Officiis III, 69.

${ }^{38}$ CÍCERO, DL I, 16-17, p. 58.

${ }^{39}$ CÍCERO, DL I, 6, p. 48.

${ }^{40}$ CÍCERO, DL I, 7, p. 49-50.

${ }^{41}$ CÍCERO, DL I, 7, p. 49-50.

${ }^{42}$ CÍCERO, DL I, 6, p. 48. 
lei como lei universal e do direito das gentes não confina a lei a uma determinada nação ou estado, como é o caso do direito civil. ${ }^{43}$ Ela é mais corretamente descrita como lei da natureza ou lei natural, tendo em vista que seu próprio princípio de derivação está na natureza humana. ${ }^{44}$

É claro que, por não enfatizar essa última relação da lei e da natureza humana e a apreensão sobre o elemento do divino na perspectiva de Cícero, muitas vezes, argumenta-se que Cícero sutilmente se dissocia, em suas declarações no primeiro livro do De Legibus, daquelas que se pensa ocorrer em De Re Publica. Esse argumento assevera que Cícero apresenta a lei natural como uma nobre mentira que, embora útil para fins políticos ${ }^{45}$ é indefensável filosoficamente. Sobre isso, Seagreve defende que, para Cícero, o fato de uma doutrina ser politicamente conveniente é realmente evidência de sua verdade retórica, conforme se constata no livro III, do De Officiis. ${ }^{46}$ De fato, pode-se afirmar que, para Cícero, existe uma correlação entre a verdade retórica e a defesa política, no sentido do que aquilo que é retoricamente verdadeiro, é politicamente adequado.

Nesse sentido, nesse caso, como no anterior, a evidência textual parece contradizer tal tese nos termos dessa afirmação, qual seja, de que o direito natural seria uma nobre mentira.

\footnotetext{
${ }^{43}$ CÍCERO, DL I, 5, p. 47.

${ }^{44}$ CÍCERO, $D L$ I, 5, p. 47-8.

${ }^{45}$ HOLTON, Marco Túlio Cicerón, 170-2. Convém ressaltar que Holton defende que, para Cícero, as idéias estoicas, ainda que não sejam teoricamente defensáveis, são absolutamente aceitáveis e salutares para a fundação política de Estados. Por isso mesmo, embora tenha rechaçado as bases da cosmologia estoicas em De Natura Deorum e De Divinatione, Ático, sendo um filósofo epicúreo, externaria uma aceitação desses ensinamentos políticos vendo-os como salutares, porque úteis para fins políticos.

${ }^{46}$ SEAGRAVE, Cicero, Aquinas, and Contemporary Issues in Natural Law Theory. The Review of Metaphysics, vol. 62, No. 3, March, 2009.

ÁGORA FILOSÓFICA

.v. 1.n. 2 (2014), pp.144-189 e-ISSN 1982-999x
} 
Mesmo Holton, a esse propósito, acastela que Cícero realmente defende a lei natural, porquanto a finalidade imediata do Arpinate ser prática, orientada para a fundação de Estados, o fortalecimento das cidades e a cura dos males do povo e, por isso mesmo, endereçada para homens decentes e honráveis, de tal sorte que há um encontro entre retórica, filosofia e política. ${ }^{47}$

É oportuno, todavia, recordar que antes de enveredar na discussão da lei natural, Cícero distinguiu o seu propósito, externado no De Legibus, como distinto daquele do advogado comum, isto é, daquele de defende uma causa. Assim,

Entre nós existiram homens ilustres que se dedicaram a interpretar esse direito para o público e a resolver casos jurídicos; no entanto, anunciando grandes projetos, consagraram-se a miudezas. Porque nada existe de mais importante que o direito do Estado e nada tão insignificante - por mais necessário que seja ao povo - que a tarefa dos que se dedicam a consultas jurídicas. Não quero dizer que tais especialistas ignoravam o direito universal, mas, ao tratarem do denominado direito civil, só o fizeram na medida em que consultavam o desejo de prestar serviços ao povo, o que, sob a ótica teórica, é insuficiente, ainda que necessário sob o aspecto prático. Para que assunto me chamas e a que me convidas? Será para escrever livretes jurídicos sobre as calhas d'água, ou as paredes divisórias, ou redigir formulários de julgamentos? Tais assuntos são batidos e, segundo creio, inferiores à nossa expectativa. ${ }^{48}$

\footnotetext{
${ }^{47}$ HOLTON, Marco Túlio Cicerón, 173-4.

${ }^{48}$ CÍCERO, DL I, 4, p. 44. No original, "Egone? Summos fuisse in ciuitate nostra uiros, qui id interpretari populo et responsitare soliti sint, sed eos magna professos in paruis esse uersatos. Quid enim est tantum quantum ius ciuitatis? Quid autem tam exiguum quam est munus hoc eorum qui consuluntur? Quam <quam> est [populo] necessarium, nec uero eos, qui ei muneri praefuerunt, uniuersi iuris fuisse expertis existimo, sed hoc ciuile quod uocant eatenus exercuerunt, quoad populo praestare uoluerunt; id autem in cogniti <one> tenue est, in usu necessarium. Quam ob rem quo me uocas, aut quid hortaris? ut libellos conficiam de stillicidiorum ac de parietum iure? An ut stipulationum et iudiciorum formulas conponam? Quae ÁGORA FILOSÓFICA .v. 1. n. 2 (2014), pp.144-189 e-ISSN 1982-999x
} 
Do exposto, depreende-se que o propósito de Cícero, tal como se encontra no De Legibus, estende-se para além daquilo que é útil, isto é, do que é apenas prático. O autor deseja, em vez disso, que seja algo filosófico, notadamente, que seja algo profundo, tão elevado quanto o aprendizado que está em causa. Há que se observar, por sua vez, que, tanto no De Legibus, quanto no De Re Publica, há um aspecto divino ao qual está vinculado, pode-se dizer, o aspecto substancial do argumento da própria natureza humana.

Não obstante, Cícero manifesta uma preocupação constante com os presentes ou dons da natureza ofertados aos homens, e, embora a discussão aponte que esses presentes ou dons possam ser perguntados como da alçada da teologia, devese dizer que são os mais profundos mistérios da filosofia. Ora, isso quer dizer que a natureza da justiça, bem como a sua origem no direito, devem ser procuradas na natureza do homem. ${ }^{49}$ Kury, ao apresentar o De Legibus, e argumentando acerca desse ser divino ao qual Cícero faz referência, afirma que "a natureza regalou-nos com grande quantidade
de bens úteis, desde as plantas até os animais
domésticos", e Deus, para "converter o homem
na razão do universo", dotou nossa existência de
"outras propriedades, além do supremo bem (a
razão)", tais como os sentidos, adaptados ao
papel de "servos e mensageiros" do homem. [...]
Frente a todos esses dotes, é impossível
desconhecer a missão que temos no universo:
nascemos para agir conforme a Natureza, que é a
execução da Lei [...]. ${ }^{50}$

et conscripta a multis sunt diligenter, et sunt humiliora quam illa quae a nobis exspectari puto."

${ }^{49}$ CÍCERO, DL I, 5, 47.

${ }^{50} \mathrm{KURY}$, Introdução, 23. In: CÍCERO, DL. Os itálicos são do autor.

ÁGORA FILOSÓFICA

.v. 1. n. 2 (2014), pp.144-189 e-ISSN 1982-999x 
como uma teoria provável que pode ser avançada para suplementar um exame da natureza do homem. ${ }^{51}$ É evidente que, nesse diálogo, acena-se para o papel inessencial (epistemologicamente, em vez de em sentido ontológico) da ideia de um Deus transcendente e, assim, da lei eterna, para se chegar a uma compreensão básica da própria natureza. Esse papel secundário é visto sob a ótica epistemológica, em oposição ao que teria sob a via ontológica, de tal modo que a remissão à Deus ou à lei eterna, para o argumento da natureza, é secundária e complementar.

Dessa feita, à luz da discussão de Cícero acerca da lei natural, a existência de um Deus não é uma premissa necessária ${ }^{52}$, mas sim, no seio dessa discussão, a natureza, vista como o elemento necessário. ${ }^{53}$ Ora, isso quer dizer que são especialmente relevantes os conceitos de natureza humana e de razão, sendo esta última uma característica distintiva daquela. Esses são, pois, os conceitos que devem ser analisados para que se perceba o modo através do qual, nos escritos de Cícero, a lei procede da natureza humana.

\subsection{Lei Natural e Natureza Humana}

O fundamento do conceito de natureza humana, em Cícero, está no lugar específico no qual estão situados os seres humanos dentro de uma hierarquia de naturezas. No início do De Officiis, Cícero descreve as características naturais, bem

\footnotetext{
${ }^{51}$ CÍCERO, $D L$ I, 8, p. 50.

${ }^{52}$ CÍCERO, $D L$ I, 9, p. 51.

${ }^{53}$ Importa ver que, dentre os argumentos de Ático para aceitar a alegação de Cícero, todos eles são fenômenos naturais. ÁGORA FILOSÓFICA .v. 1. n. 2 (2014), pp.144-189 e-ISSN 1982-999x
} 
aquelas instituais, de todas as espécies de seres vivos. Entre os principais instintos, estão a autopreservação e a reprodução, aos quais Cícero acrescenta outros que, de algum modo, são fundamentais para esses dois. No bojo da discussão sobre o dever, mais especificamente sobre a quintuplicidade da deliberação de um conselho que se toma, afirma:

[...] dotou a natureza toda a espécie de seres animados com o instinto de conservação, a fim de se evitar aquilo que parece causar sofrimento à vida ou que a incapacita, e de procurar e providenciar tudo aquilo que for necessário para a vida - comida, refúgio e outras coisas do mesmo gênero. Um aspecto comum a todas as criaturas é também o instinto de reprodução (cuja finalidade é a procriação da espécie) como ainda uma certa preocupação com os progenitores. Mas, a diferença marcante entre o homem e os animais é a seguinte: o animal, porque é comandado pelos sentidos e possui uma percepção do passado e do futuro muito pequena, só é capaz de se adaptar, ele mesmo, aquilo que é do domínio do presente, do momento; enquanto que o homem, porque é dotado de razão, pela qual compreende a relação de causa e consequência e pode estabelecer analogias, ligando e associando o presente ao futuro, compreende facilmente o curso de toda a vida, fazendo os preparativos necessários para a sua conduta. $^{54}$

Além disso, no De Legibus, em passagem que guarda certa semelhança com essa do De Officiis, Cícero afirma que, muito

54 CÍCERO, De Officiis, I, 11, p. 19. No Original: "Principio generi animantium omni est a natura tributum, ut se, vitam corpusque tueatur, declinet ea, quae nocitura videantur, omniaque, quae sint ad vivendum necessaria anquirat et paret, ut pastum, ut latibula, ut alia generis eiusdem. Commune item animantium omnium est coniunctionis appetitus procreandi causa et cura quaedam eorum, quae procreata sint. Sed inter hominem et beluam hoc maxime interest, quod haec tantum, quantum sensu movetur, ad id solum, quod adest quodque praesens est se accommodat, paulum admodum sentiens praeteritum aut futurum. Homo autem, quod rationis est particeps, per quam consequentia cernit, causas rerum videt earumque praegressus et quasi antecessiones non ignorat, similitudines comparat rebusque praesentibus adiungit atque adnectit futuras, facile totius vitae cursum videt ad eamque degendam praeparat res necessarias."

$$
\begin{gathered}
\text { ÁGORA FILOSÓFICA } \\
\text { v. 1. n. } 2 \text { (2014), pp.144-189 e-ISSN 1982-999x }
\end{gathered}
$$


embora tenha características instintuais, o homem tem, do mesmo modo, uma diferença gritante em relação aos demais seres vivos, qual seja, a da razão. Segundo Cícero,

Nada há tão semelhante, tão igual, uns aos outros, como nós entre nós. E se a depravação dos costumes e as divergentes opiniões não deformassem e dobrassem os espíritos fracos aos seus caprichos, todo o homem se assemelharia a todos, e qualquer definição que fosse dada a um serviria a todos. Tais considerações bastam para provar que não há diferenças no gênero humano. Com efeito, a razão - a única faculdade que nos coloca acima dos animais e nos torna capazes de inferir, demonstrar, refutar, discutir, resolver e concluir - é, sem dúvida, comum a todos os homens, pois, ainda que díspares no saber, possuem a mesma aptidão para aprender. Não apenas cada um dos sentidos capta objetos parecidos, mas também em cada um os objetos impressionam os sentidos da mesma forma. Essas impressões - que são primeiras noções a que me referi - são idênticas em todos, e a mente, ao expressar o discurso, mesmo empregando termos distintos, expressa significados semelhantes. Não há indivíduo, pertença à raça que pertencer, que não consiga, sob a condução da Natureza, alcançar a virtude. ${ }^{55}$

O que é notável, nessas duas passagens, é que Cícero principia listando descritivamente as capacidades adequadas, bem como as inclinações inerentes à razão, isto é, certas

${ }^{55}$ CÍCERO, DL I, 10, p. 52. No original: "Nihil est enim unum uni tam simile, tam par, quam omnes inter nosmet ipsos sumus. Quodsi deprauatio consuetudinum, si opinionum varietas non inbecillitatem animorum torqueret et flecteret, quocumque coepisset, sui nemo ipse tam similis esset quam omnes sunt omnium. Itaque quaecumque est hominis definitio, una in omnis ualet. Quod argumenti satis est nullam dissimilitudinem esse in genere. Quae si esset, non una omnis definitio contineret. Etenim ratio, qua una praestamus beluis, per quam coniectura ualemus, argumentamur, refellimus, disserimus, conficimus aliquid, cuncludimus, certe est communis, doctrina differens, discendi quidem facultate par. Nam et sensibus eadem omnium conprehenduntur, et ea quae mouent sensus, itidem mouent omnium, quaeque in animis imprimuntur, de quibus ante dixi, inchoatae intellegentiae, similiter in omnibus imprimuntur, interpresque mentis oratio uerbis discrepat, sententiis congruens. Nec est quisquam gentis ullius, qui ducem naturam nactus ad uirtutem peruenire non possit."

ÁGORA FILOSÓFICA

.v. 1. n. 2 (2014), pp.144-189 e-ISSN 1982-999x 
potencialidades que pertencem à racionalidade, poder-se-ia dizer. Entre essas capacidades, tal como indicado na citação, como Cícero concebe, estão:
a) Capacidade de fazer inferências e demonstrar;
b) Capacidade para refutar, discutir e resolver problemas;
c) Capacidade para perceber as causas das coisas;
d) Capacidade para ligar e associar o presente o futuro.

Essas são capacidades em relação às quais o ser humano, em virtude apenas de ter razão, já as possui. Tratam-se, efetivamente, de capacidades intrínsecas à racionalidade. Contudo, Cícero lista, igualmente, certas inclinações próprias da razão. Entre as quais, tem-se:

a) o impulso de formar comunidades com outros seres humanos para fornecer armazenamento de coisas ${ }^{56}$, tanto para si como para os outros em seus cuidados; e

b) para buscar a verdade. ${ }^{57}$

Ademais de apresentar as capacidades e as inclinações da razão, o autor, por uma questão de completude, lista igualmente os males, isto é, as más tendências inerentes à natureza humana em virtude da racionalidade. ${ }^{58}$ Em resumo, essas más tendências são as que vão contra o bem da razão, em geral, incluídas sob o título de prazer (prazer sexual), que, além disso, estão associadas a outros animais, exempli gratia, os bovinos, os equinos, entre outros, os quais são impelidos à realizar tal tendência de forma irracional e irrefletida. ${ }^{59}$

A questão crucial nessa matéria, como bem esclarece Seagrave, ancorando-se em Nicgorski, é que tanto as boas

${ }^{56}$ CÍCERO, De Officiis, I, 12.

${ }^{57}$ CÍCERO, De Officiis, I, 12.

${ }^{58}$ CÍCERO, DL I, 11, p. 52.

${ }^{59}$ CÍCERO, De Officiis, I, 105. 
quanto as más inclinações, isto é, as inclinações referentes à razão e aquelas ao apetite sexual, são naturais aos seres humanos. ${ }^{60} \mathrm{O}$ problema de decidir entre essas inclinações na correta determinação das ações, para Cícero, não existe em virtude de que o aspecto racional no homem é claramente superior ao do animalesco ou àquelas referentes ao prazer.

É preciso mais e, para isso, Cícero vale-se do conceito de virtude. O autor, então, explica a virtude geral do decoro e seu dever correspondente, o qual envolve um dever geral de viver de acordo com a natureza posto que há duas forças operando no ser humano: uma força é o apetite, o qual impele-o a viver desta ou daquela maneira; a outra é a razão, a qual ensina e explica o que deve ser feito e o que deve ser deixado de lado. Ora, como resultado dessas forças, Cícero afirma que a razão comanda e o apetite, por sua vez, obedece. ${ }^{61}$ Assim, segundo Cícero,

O poder do espírito - tal é a sua natureza! - é efetivamente duplo: uma parte, que é constituída pela horme grega, reside nos desejos que arrastam o homem ora por aqui ora por acolá; a outra razão reside na razão, que ensina a explicar aquilo que deveria ser feito bem como aquilo que se deveria evitar fazer. O resultado é, pois, a razão comandar e o apetite obedecer. ${ }^{62}$

É notável que, muito embora essa passagem surja no contexto das discussões sobre as virtudes, ela evoca indubitavelmente muitas formulações da lei natural nos escritos do autor. Ora, sendo esse o caso, é perfeitamente plausível

\footnotetext{
${ }^{60}$ SEAGRAVE, Cicero, Aquinas, and Contemporary Issues in Natural Law Theory. The Review of Metaphysics, vol. 62, No. 3, March, 2009.

${ }^{61}$ CÍCERO, De Officiis, I, 101.

${ }^{62}$ CÍCERO, De Officiis, I, 101. No original: "Duplex est enim vis animorum atque natura; una pars in appetitu posita est, quae est orme Graece, quae hominem huc et illuc rapit, altera in ratione, quae docet et explanat, quid faciendum fugiendumque sit. Ita fit, ut ratio praesit, appetitus obtemperet."

ÁGORA FILOSÓFICA .v. 1. n. 2 (2014), pp.144-189 e-ISSN 1982-999x
} 
conjecturar que o Arpinate deriva tanto a lei natural como as virtudes de um único manancial, vale dizer, a natureza humana.

\section{Segundo Cícero,}

[...] examinemos os princípios básicos do Direito. Aos autores de nomeada agrada começar pela Lei e, certamente, não se equivocam se, por definição, a Lei for a razão suprema, impressa na Natureza, que ordena o que se deve fazer e proíbe o contrário. Essa mesma razão, quando fixada e desenvolvida na mente humana, converte-se na Lei.

Por isso, sustenta-se que a razão prática é a lei cuja força consiste em exigir as boas ações e vetar as más; [...] Se tudo o que foi dito é certo, como creio que genericamente o é, a origem do Direito está na Lei. Ela é a força da Natureza; ela, a mente e a razão prática; ela, o critério do justo e do injusto. ${ }^{63}$

Apesar de ser uma clara e lúcida afirmação, como aponta

Seagrave, ela encontra um sério problema, porque parece ser a óbvia exemplificação da falácia naturalista ${ }^{64}$ afirmada por Hume, falácia esta que, segundo teóricos como Finnis e George, refuta decisivamente a imagem mais popular da lei natural e, de

${ }^{63}$ CÍCERO, DL I, 4, p. 48. No original: "Igitur doctissimis viris proficisci placuit a lege, haud scio an recte, si modo, ut idem definiunt, lex est ratio summa, insita in natura, quae iubet ea quae facienda sunt, prohibetque contraria. Eadem ratio, cum est in hominis mente confirmata et perfecta, lex est. [...] Itaque arbitrantur prudentiam esse legem, cuius ea uis sit, ut recte facere iubeat, vetet delinquere [...]. Quod si ita recte dicitur, ut mihi quidem plerumque uideri solet, a lege ducendum est iuris exordium. Ea est enim naturae uis, ea mens ratioque prudentis, ea iuris atque iniuriae regula."

${ }^{64}$ Dá-se o nome falácia naturalista para a pretensão que doutrinas, mormente o jusnaturalismo, de concluir juízos de valor a partir de fatos. Em geral, adota a posição segundo a qual do ser não se segue nenhum dever. Moore, em seu Principia Ethica, formulou mais claramente a nomenclatura. Entretanto, passando por Sidgwick, ela remete à impossibilidade, enunciada por Hume, em Tratado da natureza humana, de não se poder derivar dever de ser. Finnis aborda essa questão em Lei Natural e Direitos Naturais, nas páginas 47 a 53, nas quais, entre outras coisas, afirma que essa crítica não pode ser endereçada a pensadores como Tomás de Aquino, em virtude de este, ao procurar descobrir o que moralmente certo (virtude) e errado (vício) é perguntar não o que está de acordo com a natureza humana, mas o que é razoável, de tal sorte que, nesse conjuntura, remete-se aos primeiros princípios da razoabilidade prática. Cf. FINNIS, Lei Natural e Direitos Naturais, 47.

ÁGORA FILOSÓFICA

.v. 1. n. 2 (2014), pp.144-189 e-ISSN 1982-999x 
alguma forma, exige o projeto dos novos teóricos do direito natural. ${ }^{65}$

Com efeito, Cícero constrói uma teoria normativa das virtudes e da lei natural usando uma perspectiva descritiva da natureza humana, algo diverso do que ocorre na falácia naturalista. É importante ter presente que a perspectiva descritiva de Cícero da natureza humana, como acenado acima, envolve dois tipos de fatos, os quais existem numa complexa relação de ordem hierárquica e oposição, em termos de potência, a saber:

i) a superioridade da razão e de suas determinações aos impulsos cegos do apetite sensual;

ii) o poder do apetite sensual para reverter essa ordem hierárquica de tal modo a influenciar a ação humana, apesar do comando da razão.

Contudo, da capacidade da razão para a reflexão e para a deliberação - e seu impulso para orientar e restringir as paixões potencialmente rebeldes - surge a possibilidade humana de escolha. Com isso, Cícero quer fazer com que o homem, muito mais do que ser determinado por suas paixões, seja capaz de fazer escolhas de forma livre, a partir de uma perspectiva descritiva da natureza humana. Nesse sentido, a própria noção de lei surge desse relato descritivo da natureza humana, através de duas formas.

i) A lei como implicação inerente a natureza humana;

ii) A lei como instância nos comandos de ação oriundas da razão.

A primeira delas, como indicado, considera que a lei seja uma implicação inerente da natureza humana, tendo em vista

\footnotetext{
${ }^{65}$ SEAGRAVE, Cicero, Aquinas, and Contemporary Issues in Natural Law Theory. The Review of Metaphysics, vol. 62, No. 3, March, 2009.

ÁGORA FILOSÓFICA .v. 1. n. 2 (2014), pp.144-189 e-ISSN 1982-999x
} 
que as inclinações próprias dessa natureza sejam realizadas apenas como potencialidades em conformidade com o poder contingente de escolha. ${ }^{66}$ Isso quer dizer, em outras palavras, que o ser da natureza humana está potencialmente em constante conflito com as ações humanas particulares. Os fatos da natureza humana incluem a inclinação primária, ou regra geral, para agir de acordo com essa natureza. Essa regra geral torna-se um comando quando se confronta com a indeterminação da escolha.

De forma mais clara, a regra para agir de acordo com a natureza humana possui a forma de um comando, em vez de um conselho ou recomendação, uma vez que inclui a ameaça de punição e a promessa de recompensa - concebidas como efeitos próprios da noção de comando. $O$ castigo ameaçado pelo comando, ou lei da natureza, consiste principalmente na alienação de si mesmo a partir de sua natureza, isto é, a incapacidade de ser, na realidade, o que se é, no sentido de poder vir a ser, fundamental e potencialmente. Esse efeito, para Cícero, qual seja, o de não se tornar o que se pode ser, é a mais dura das penalidades. A não realização gera sanções e, embora pareça claro, como resultado de seu afastamento a partir de experiência concretas de danos físicos ou financeiros, a sanção mais dolorosa necessariamente, tendo em vista que o desejo mais fundamental de qualquer ser natural consiste na preservação da sua natureza, é a não realização da própria natureza. Dessa maneira, o comando da natureza humana inclui, também, inversamente, a recompensa da virtude, isto é, a

\footnotetext{
${ }^{66}$ CÍCERO, DL I, 7, p. 48.

ÁGORA FILOSÓFICA

.v. 1.n. 2 (2014), pp.144-189 e-ISSN 1982-999x
} 
realização extremamente vantajosa assim como a realização da própria natureza.

Além disso, esse conflito potencial, como resultado do poder da escolha, e o comando implícito à natureza humana, estão presentes no ser humano tomado individualmente. Ora, isso quer dizer que o homem sabe que deve agir de acordo com o que ordena a razão, depois de refletir que o cumprimento de sua natureza requer que aja de acordo com o que ordena a razão. Assim, Seagrave, ancorando-se em Crosson e Fortin, afirma que a lei natural deriva a sua existência como lei a partir dos fatos interrelacionados na natureza humana, porque existe como um comando geral, o qual pode ser seguido ou rejeitado e que inclui recompensas intrínsecas e penalidades inerentes, quando do desvio. $^{67}$ Dessa forma, é universalmente promulgada aos indivíduos que conhecem, que sabem, que se valem, portanto, da razão. $^{68}$

A segunda forma através da qual surge a noção de lei é tal que a lei natural existe através da sua instanciação nos comandos específicos da ação que são emitidos pela razão do indivíduo como respostas às circunstâncias empíricas, e, portanto, concretas. É nesse segundo modo que se entende a afirmação de Cícero de que a lei é a mente e a razão do homem prudente, o padrão pelo qual a justiça e a injustiça são medidas. ${ }^{69}$ Diversamente do primeiro modo que considerava a

\footnotetext{
${ }^{67}$ SEAGRAVE, Cicero, Aquinas, and Contemporary Issues in Natural Law Theory. The Review of Metaphysics, vol. 62, No. 3, March, 2009.

${ }^{68}$ É interessante questionar se a educação tem alguma funcionalidade nesse processo que conduz ao conhecimento da lei natural. Entretanto, por uma questão de economia do texto, essa questão não será abordada nessa pesquisa.

${ }^{69}$ CÍCERO, DL I, 7, p.48. 
lei natural como relativa a todo ser humano, na segunda forma ela terá como sujeito o apetite sensual.

Sendo assim, uma vez que a natureza da razão, incluindo suas inclinações próprias, implica dirigir todas as ações dos seres humanos, ela deve, então, emitir comandos específicos para o menor apetite de tal modo a que este se porte conforme o comando. No entanto, esse apetite está habituado a se opor aos comandos da razão e é capaz de, apesar dos comandos, determinar as ações humanas. Essa capacidade de oposição e resistência, como sua primeira e mais geral manifestação, elimina a possibilidade de um tipo de determinação despótica e necessita, então, de uma regra como e por lei. Dessa feita, nesse segundo modo, o indivíduo, seguindo injunções da primeira manifestação da lei natural, emite comandos aos seus apetites, os quais possuem o caráter de lei natural, na forma de participação particular.

Se se exluir essa derivação explícita da lei natural, a perspectiva de Cícero em muito, notavelmente, assemelha-se àquela que elabora Aristóteles. Há certa ideia de natureza em Cícero que, de algum modo, é muito próxima àquela que Aristóteles desenvolveu. Sendo assim, é conveniente discutir-se, mesmo que brevemente, a ideia de natureza em Aristóteles, a qual, segundo se defende, guarda semelhança com a de Cícero.

\section{Natureza e Natureza Humana em Aristóteles}

Consoante o que se indicou, a perspectiva de Cícero, no que respeita à questão da natureza, é muito próxima daquela que Aristóteles desenvolveu. Na Física, como se lê, Aristóteles 
define a natureza, em geral, tanto em contraposição à sorte e ao azar como, também, em relação ao que é sempre, ou na maioria das vezes, e ao que é inerente aos seres como origem ou causa de seu movimento e repouso. ${ }^{70}$ Nesse sentido, pode-se entender a extensão da afirmação segunda a qual a natureza é princípio e causa do movimento ou do repouso na coisa a que pertence primariamente e por si mesma, e não por acidente. ${ }^{71}$ Para Aristóteles, vale dizer, como sugere Echandía, essa afirmação

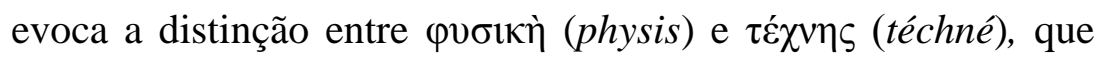
são dois princípios distintos de coisas. Como todo ente emerge

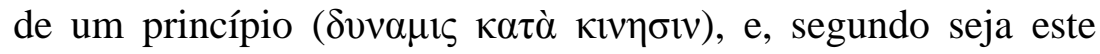
intrínseco ou extrínseco, tal emergência será um nascimento natural de coisas ou uma produção artificial delas. Ora, esses modos de proveniência determinam dois tipos contrapostos e excludentes de entes, pois a $\tau \varepsilon ́ \chi v \eta \varsigma$ (téchné) somente produz artefatos, coisas que, uma vez produzidas, carecem de atividade natural, ao passo que a atividade natural é uma característica do que é por natureza. ${ }^{72}$ Além disso, a natureza como origem e causa de seu movimento e repouso constitui a definição essencial de natureza, que se identifica com a forma, isto é, com a alma. $^{73}$

Así, en este otro sentido, la naturaleza de lo que tiene en sí mismo el principio del movimiento sería la forma o la especie, la cual sólo conceptualmente es separable de la cosa. En cuanto a lo que está compuesto de materia y forma, por ejemplo un hombre, eso no es naturaleza, sino por naturaleza.

\footnotetext{
${ }^{70}$ ARISTÓTELES, Física, 195b 30-200b 10.

${ }^{71}$ ARISTÓTELES, Física, 192b 20-2.

${ }^{72}$ ARISTÓTELES, Física, 192b 20. As afirmações são oriundas das notas 104-9, de Guillermo R. de Echandía.

${ }^{73}$ ARISTÓTELES, Física, 193a-193b 1-22. 
La forma es más naturaleza que la materia, porque decimos que una cosa es lo que es cuando existe actualmente más que cuando existe en potencia. $^{74}$

Na Ética a Nicômaco, no contexto da discussão sobre a

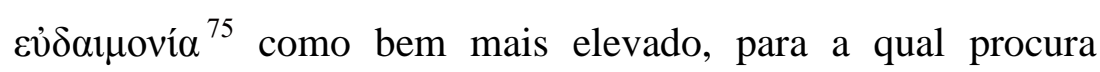
perscrutar a função do homem, Aristóteles aplica essa discussão da natureza aos seres humanos, tal como Cícero, e, também como ele, principia comparando a natureza humana com outras naturezas, de tal modo a estabelecer uma hierarquia de naturezas. Ora,

A vida parece ser comum até às próprias plantas, mas agora estamos procurando o que é peculiar ao homem. Excluamos, portanto, a vida de nutrição e crescimento. A seguir há uma vida de percepção, mas essa também parece ser comum ao cavalo, ao boi e a todos os animais. Resta, pois, a vida ativa do elemento que tem um princípio racional; desta, uma parte tem tal princípio no sentido de ser-lhe obediente, e a outro no sentido de possuí-lo e de exercer o pensamento. E, como a vida do elemento racional também tem dois significados, devemos esclarecer aqui que nos referimos a vida no sentido de atividade; pois esta parecer ser a acepção mais própria do termo. ${ }^{76}$

Dessa forma, dando à natureza humana o mesmo elemento formal identificado por Cícero, que é a razão, Aristóteles passa,

74 ARISTÓTELES, Física, 193b 2-7. Nas notas, Echandía faz uma importante observação que lança luz às afirmações de Cícero e sua relação com as de Aristóteles. Assim, segundo explica, uma coisa alcança propriamente seu $\tau \dot{\lambda} \lambda \mathrm{o}$ (fim) quando logra plenamente o $\varepsilon i \delta o \varsigma$ para o qual está disposta por natureza.

${ }^{75}$ Como Ross explica, "A tradução convencional por «felicidade»é imprópria a respeito da Ética, pois, enquanto «felicidade» designa um estado de sentimento, diferindo do «prazer» apenas pela sua sugestão de permanência, de profundidade e de serenidade, Aristóteles insiste no facto de

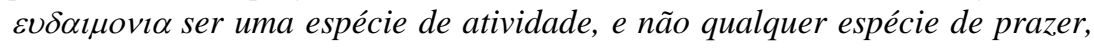
apesar de este a acompanhar naturalmente. Por isto, será preferível traduzir mais prudentemente por «bem-estar»." Cf. ROSS, Aristóteles, 196. Tendo

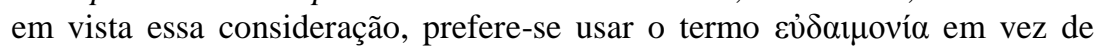
qualquer outro termo.

${ }^{76}$ ARISTÓTELES, Ética a Nicômaco, 1097b 34-1098a 5.

ÁGORA FILOSÓFICA

.v. 1.n. 2 (2014), pp.144-189 e-ISSN 1982-999x 


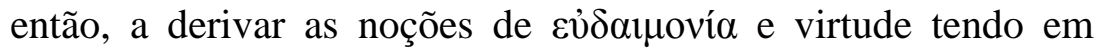
vista $\tau \varepsilon \lambda o s$ humano. No curso dessa derivação, como se percebe, encontra os mesmos elementos conflitantes da natureza humana que são igualmente observadas por Cícero. Cabe observar que o estagirita divide a alma humana, a natureza humana no sentido formal, em:

i) Elementos racionais; e

ii) Elementos irracionais, os quais são naturalmente opostos aos princípios racionais, de tal forma a serem capazes de combatê-lo e resisti-los. ${ }^{77}$

Estabelecendo essa distinção, Aristóteles demonstra já possuir uma perspectiva complexa e dinâmica de inclinações naturais hierarquicamente ordenadas e potencialmente opostas, que serão retomadas posteriormente por Cícero para a sua teoria da lei natural. Não obstante a recorrente identificação com a lei natural a passagem na qual Aristóteles fala sobre a justiça política e sua parte natural ${ }^{78}$, pode-se ver certa conexão com a doutrina da lei natural em sua discussão da continência e incontinência no Livro VII, da Ética a Nicômaco. Nessa última discussão, Aristóteles descreve a percepção, tendo como

\footnotetext{
${ }^{77}$ ARISTÓTELES, Ética a Nicômaco, 1102b 13-30.

${ }^{78}$ Assim, diz Aristóteles: "Da justiça política, uma parte é natural e outra parte legal: natural, aquela que tem a mesma força onde quer que seja e não existe em razão de pensarem os homens deste ou daquele modo; legal, a que de início é indiferente, mas deixa de sê-lo depois que foi estabelecida [...]." Cf. ARISTÓTELES, Ética a Nicômaco, 1134b 18-22. Também, na Retórica: "Distingamos agora todos os actos de injustiça e de justiça, começando por observar que o que é justo e injusto foi já definido de duas maneiras em relação a dois tipos de leis e a duas clases de pessoas. Chamo lei tanto à que é particular como à que é comum. É lei particular a que foi definida por cada povo em relação à si mesmo, quer seja escrita ou não escrita; e comum, a que é segundo a natureza. Pois há na natureza um princípio comum do que é justo e injusto, que todos de algum modo adivinham mesmo que não haja entre si comunicação ou acordo [...]." Cf. ARISTÓTELES, Retórica, I, 13, 1373b.
}

ÁGORA FILOSÓFICA

.v. 1. n. 2 (2014), pp.144-189 e-ISSN 1982-999x 
referência as peculiaridades da natureza humana. ${ }^{79}$ Essas peculiaridades indicam a presença simultânea dentro do indivíduo de uma opinião universal, a qual comanda ou proíbe, de acordo com a razão, e um apetite que resiste a esse comando. ${ }^{80}$ Sendo assim, um homem se comporta incontinentemente sob a influência (num sentido) de uma razão e de uma opinião que não é contrária em si mesma à reta razão, tendo em vista o apetite ser contrário, mas não a opinião. ${ }^{81}$

Por essa razão, Aristóteles também afirma que os animais inferiores não são incontinentes precisamente porque não têm juízo universal, o qual se refere apenas à razão. ${ }^{82}$ Seagrave argumenta que o reconhecimento de Aristóteles e a discussão complexa dos fenômenos de restrição e sensualidade, acrescentam uma dimensão importante à sua filosofia moral, dado esse muitas vezes esquecido por estudiosos que tentam dissociar o direito natural aristotélico das teorias do direito natural. $^{83}$

Assim, é dentro dessa discussão que Aristóteles apresenta sua análise da natureza humana, em geral, como conclusão, a partir de premissas universais e de uma premissa particular. As premissas universais consistem em proposições que expressam uma verdade prática, tais como, 'alimento seco é bom para todos', 'eu sou um homem'. ${ }^{84}$ Ora, essas premissas universais se juntam para formar comandos gerais ou proibições formuladas pela razão e dirigidas ao ser humano como um agente

\footnotetext{
${ }^{79}$ ARISTÓTELES, Ética a Nicômaco, 1147a 25.

${ }^{80}$ ARISTÓTELES, Ética a Nicômaco, 1147a 30-35.

${ }^{81}$ ARISTÓTELES, Ética a Nicômaco, $1147 \mathrm{~b}$.

${ }^{82}$ ARISTÓTELES, Ética a Nicômaco, 1147a 4-6.

${ }^{83}$ SEAGRAVE, Cicero, Aquinas, and Contemporary Issues in Natural Law Theory. The Review of Metaphysics, vol. 62, No. 3, March, 2009.

${ }^{84}$ ARISTÓTELES, Ética a Nicômaco, 1147a 5-7.$$
\text { ÁGORA FILOSÓFICA }
$$$$
\text { .v. 1. n. } 2 \text { (2014), pp.144-189 e-ISSN 1982-999x }
$$ 
preocupado com ações particulares. É notável que, no exemplo de Aristóteles, pode haver opinião universal presente em nós não apenas indicando que deve abster-se de realizar alguma ação, mas, na verdade, nos proibindo de executar a ação. ${ }^{85}$ Como Aristóteles não indica que sua análise da ação humana nesse lugar, Seagrave conclui só se aplica a pessoas sem restrições, pode-se supor que a pessoa de sabedoria prática

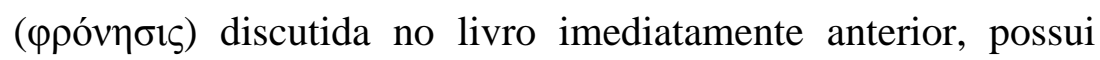
semelhantes premissas universais de ação que têm esse caráter comandante e proibitivo. ${ }^{86}$

Para Aristóteles, o homem prudente, em seguida, distingue-se do homem contido no seguinte ponto: uma vez que os seus apetites e paixões foram devidamente habituados, eles não dão origem a premissas e causas concorrentes que impedem a eficácia da regra do que é certo. Nessa análise da ação humana, a qual é a base da análise da alma humana, o pensamento de Aristóteles parece se aproximar de um conceito de lei natural. ${ }^{87}$ Embora Aristóteles não tenha chegado a esse conceito próprio, Cícero mostra, em seus escritos, que a noção de lei é, de fato, implícita numa perspectiva aristotélica da natureza humana. Dessa feita, Cícero estabelece, então, as bases para a teoria da lei natural em pilares conceituais da natureza de Aristóteles.

\section{Direito e Justiça na Re Publica de Cìcero}

\footnotetext{
${ }^{85}$ ARISTÓTELES, Ética a Nicômaco, 1147a 32.

${ }^{86}$ SEAGRAVE, Cicero, Aquinas, and Contemporary Issues in Natural Law Theory. The Review of Metaphysics, vol. 62, No. 3, March, 2009.

${ }^{87}$ SEAGRAVE, Cicero, Aquinas, and Contemporary Issues in Natural Law Theory. The Review of Metaphysics, vol. 62, No. 3, March, 2009.

ÁGORA FILOSÓFICA .v. 1. n. 2 (2014), pp.144-189 e-ISSN 1982-999x
} 
Como sugere Harries, Cícero tinha clareza de que, como advogado, não era conveniente mostrar-se mais como intelectual do que como defensor ao abordar seu público no Fórum em virtude de as leis da natureza serem afastadas da percepção da multidão. ${ }^{88}$ Isso não impediu que a prática forense de Cícero não animasse a reflexão filosófica que desenvolveu. A história mostra o inverso: em sua teorização sobre o direito, o Arpinate teve como norte à reflexão a prática forense.

E, uma vez que se tenha tergiversado sobre a lei natural, cabe, por agora, explanar sobre o direito e a justiça a qual, tal como aquele, é enraizada também na natureza humana. Pode-se dizer, previamente, que o significado geral da lei natural, como sustenta Kury, consiste em observar a justiça, solidificar os vínculos sociais e agir como membro consciente do gênero humano $^{89}$, e, para tal, a vivência numa comunidade política e jurídica. Nesse sentido,

[...] existe um só direito, aquele que une a sociedade humana e que nasce de uma só Lei; e essa Lei é a reta razão, quando ordena ou proíbe. Quem a ignorar é injusto, esteja ou não escrita em algum lugar. Se a Justiça consistisse em obedecer às leis escritas e agir conforme as instituições dos povos, [...] tudo seria medido pelo padrão de utilidade e qualquer um, quando lhe fosse proveitoso, poderia ignorar ou violar as leis. Resulta daí que não existe justiça se não assentada na Natureza [...]. ${ }^{90}$

\footnotetext{
${ }^{88}$ HARRIES, Cicero and the Law, 147.

${ }^{89}$ KURY, Introdução, 25, In: CÍCERO, DL.

${ }^{90}$ CÍCERO, DL I, 15, p. 57. No original: "Est enim unum ius quo deuincta est hominum societas et quod lex constituit una, quae lex est recta ratio imperandi atque prohibendi. Quam qui ignorat, is est iniustus, siue est illa scripta uspiam siue nusquam. Quodsi iustitia est obtemperatio scriptis legibus institutisque populorum, et si [...] utilitate omnia metienda sunt, negleget leges easque perrumpet, si poterit, is qui sibi eam rem fructuosam putabit fore. Ita fit ut nulla sit omnino iustitia, si neque natura est [...]."$$
\text { ÁGORA FILOSÓFICA }
$$$$
\text { .v. 1.n. } 2 \text { (2014), pp.144-189 e-ISSN 1982-999x }
$$ 
Explicando essa passagem, Valente argumenta que o direito, nesse caso, é tomado em seu aspecto unificador, de tal forma a opor-se à diversidade, espacial ou temporal, das leis e dos costumes políticos, decretando, por consequinte, a justiça e a injustiça. Como afirma,

O Direito é, de certa maneira, a interioridade da Lei, que se volta para a sociedade política, rede de direitos e deveres, trama, sobre a qual se tecem as relações humanas de interdepência e de comunidade, pelo que se constitui toda a sociedade particular. Mas recebe, ele próprio, a sua força unificadora da Lei, que abrange a humanidade inteira na unidade natural racional, $\mathrm{e}$ que, anterior ao seu desenvolvimento histórico, preside à instituição do Direito. ${ }^{91}$

Considerando que, para Cícero, o direito seria, assim, oriundo da lei natural, derivada da natureza humana, que, conjugado ao senso prático romano, orientaria a dimensão social da civitas, caberia perguntar como direito e justiça relacionamse no pensamento do Arpinate. Para Harries, na linha do que se disse antes, Cícero coadunou a perspicácia prática de não ser ininteligível diante dos tribunais com um esforço orientado, por ele mesmo, para o consenso júris, o qual estaria na base da formação do populus e na res publica, tendo em vista ter argumentado sobre esses pontos sociais importantes, em $D e$ Re Publica. ${ }^{92}$ Embora se possa enveredar por uma análise da prática

${ }_{91}^{91}$ VALENTE, A Ética Estóica em Cícero, 303.

92 HARRIES, Cicero and the Law, 147. Segundo Harries, pode-se argumentar que esse "iuris consensus" subjacente é o direito, os acordos sociais pressupostos sobre a lei e os direitos que ele mesmo tinha argumentado em De Republica, e que era necessário para a formação de um populus e para a existência de uma res publica. Esse consenso sobre a lei se expressa, em parte, por meio das várias formas da lei escrita bem como nas suas modificações em resposta às mudanças sociais. A lei escrita era finita, tendo em vista ser escrita, mas o jus não consiste apenas no que foi escrito. Além disso, Harries explica que o consenso descançou em conceitos sociais e legais, tais como, aequitas (justiça proporcional), e consuetudo (costume), os ÁGORA FILOSÓFICA

.v. 1.n. 2 (2014), pp.144-189 e-ISSN 1982-999x 
forense de Cícero, a questão aqui é mais ampla, perguntando-se pelo fundamento, se houver um, dessa prática jurídica que Cícero tão brilhantemente trilhou. ${ }^{93}$

Embora se possa argumentar para uma proximidade com o estoicismo, no se refere à análise da justiça, a ideia de natureza que orienta a investigação em torno de Cícero, conforme se tem procurado defender, é mais próxima de Aristóteles do que daquela dos estoicos. E, nesse sentido, que a justiça é procedente da lei natural. E, sendo assim, a justiça é mais um princípio do direito - se se quiser, em alguns casos, uma regra de conduta social - do que uma autêntica virtude ética, como se encontra na influente tradição grega.

Com frequência, Cícero põe em relevo a natureza social da justiça, a qual é considerada como princípio essencial da organização social, tendo em vista dar a cada um o seu, e, por consequência, ser um dos principais caracteres da vida social. Nesse sentido, a formulação de acordo com a qual a justiça é o habitus do espírito, o qual, respeitando a utilidade comum, atribui a cada um a sua dignitas não apenas identifica a dimensão social da justiça, dentro de um Estado, mas marca decisivamente a influência da perspectiva de Cícero, sobretudo na idade média por constituir a base da interpretação de Santo Agostinho. $^{94}$

quais eram, também, questões legítimas para a disputa jurídica., significando, por isso mesmo, que a argumentação jurídica pode ser baseada estritamente em tecnicismos e, amplamente, em princípios jurídicos e na percepção social (ou popular).

93 Embora o republicanismo de Cícero seja um dos pontos mais frequentemente estudados de sua obra, essa temática, por uma questão de economia do texto, não será abordada, além da breve indicação que textualmente se faz.

${ }^{94}$ FASSÒ, História de la Filosofia del Derecho - Antiguidad y Edad Media, 95. 
Não obstante, Cícero considera que a justiça surge como atuação concreta dos preceitos do ius naturae. Ocorre que, ligados à justiça, estão o respeito à dignitas de cada um, ao serviço à utilitas communis, à erga deos religios, entre outros, de modo que o honestum e o rectum não são outra coisa que a realização prática do iustum natura. Deste ponto de vista, como afirma Martinez, ancorando-se em Costa, a justiça se corresponde com a honestas e com o officium, que é o cumprimento das normas de conduta fixadas pela natureza para o homem como ser consciente, pensamente e predestinado à sociabilidade. ${ }^{95}$ Ademais, como explica Salgado,

A justiça é [...] o máximo explendor da virtude "virtutis splendor est maximus" - porque se refere ao indivíduo e à sociedade, e seu primeiro momento é não fazer mal a ninguém, a não ser para defender-se de uma injúria. A justiça nas relações privadas: res privata, "usar o que é comum como comum e o que é privado como seu.” A justiça nas relações com o Estado: res publica. ${ }^{96}$

No entanto, essa sociabilidade implica uma comunidade organizada pelo direito. Para Cícero, o populus é o corpo de homens reunidos por um acordo comum no sentido de um respeito ao direito (iuris consensus) e associados por uma comunidade de interesses (utilitatis communiones sociatus). Assim, lê-se que é

[...] a República coisa do povo, considerando tal, não todos os homens de qualquer modo congregados, mas a reunião que tem seu fundamento no consentimento jurídico e na utilidade comum. Pois bem: a primeira causa dessa agregação de uns homens a outros é menos

\footnotetext{
${ }^{95}$ MATINEZ, Libertas Populi Romani, p. 186.

${ }^{96}$ SALGADO, O Humanismo de Cícero: a Unidade da Filosofia e Vida Política e Jurídica, 168. 
a sua debilidade do que um certo instinto de sociabilidade em todos [natural]. ${ }^{97}$

Ora, essa passagem desperta algumas questões significativas bem como algumas consequências impactantes, as quais, segundo Martinez, apoiando-se em Sabine, podem ser arroladas em três proposições:

i) a autoridade procede do povo;

ii) tal autoridade pode ser exercida somente com respaldo do direito;

iii) e, sendo autoridade, está submetida à lei moral ou natural. ${ }^{98}$

É interessante recordar que, ao tempo da República, a lei designava a regra obrigatória, colocada pela autoridade competente, a qual, nessa direção, funda as possibilidades do certo e do justo. A lei, assim, adquiria o status de representante da vontade popular que tem por princípio o interesse comum dos homens e, por alicerce, o consentimento da maioria. Para Cícero, vale dizer, a justiça, tendo natureza social, é oriunda da lei natural, a qual, por sua vez, tem a natureza humana como fundamento. Decorre disso que a lei, consoante à lei natural, é a lei que o homem, verdadeiramente homem, dá-se a si mesmo. ${ }^{99}$

Como se lê nos textos de Cícero, a forma ideal do povo, enquanto civitas, seria um regime misto, no qual a monarquia, a aristocracia e a democracia se equilibram entre si, evitando a degeneração em formas tais quais a tirania, a oligarquia e a

\footnotetext{
${ }^{97}$ CÍCERO, De Re Publica, I, 25, p. 30. No original: “[...] res publica res populi, populus autem non omnis hominum coetus quoquo modo congregatus, sed coetus multitudinis iuris consensu et utilitatis communione sociatus. Eius autem prima causa coeundi est non tam inbecillitas quam naturalis quaedam hominum quasi congregatio"

${ }^{98}$ MATINEZ, Libertas Populi Romani, p. 186.

${ }^{99}$ FASSÒ, História de la Filosofia del Derecho - Antiguidad y Edad Media, 97.
} 
anarquia, todas elas visceralmente opressoras. ${ }^{100}$ Nessa concepção de Estado, que irá repercutir em filósofos modernos, a res publica populi romani aparece essencialmente ligada à uma ordem jurídica baseada na lei e no direito. De facto, a lex publica romani vem a ser a expressão mais alta da vida política republicana desde o ponto de visto jurídico-político. Tendo-se em conta a relação estreita que Cícero estabelece entre o ius e a civitas, tem-se abalizado que nele se encontra a mais alta formulação do Estado romano, entendido como res publica, isto é, como pertencente ao populus. ${ }^{101}$

Na res publica, na ordem das relações particulares, isto é, no ius civile, que é o direito peculiar do povo romano, e que deve estar calcado no consensus iuris, tem-se que a prática jurídica do direito positivo deve respeitar alguns princípios fundamentais, entre os quais, Fassò põe em tela dois principais, a saber, a aequitas e a certeza. A aequitas, que é um princípio moral que é realizado positivamente na forma jurídica, consolida-se no direito civil, isto é, o ius civile é a aequitas

\footnotetext{
${ }^{100}$ Essa forma de república ideal, cuja investigação constitui o norte conceitual do De Re Publica, é grandemente inspirada em Políbio.

${ }^{101}$ Uma questão interessante levantada por Martinez, apoiando-se em Frasini e Cassirer, diz respeito ao estado de direito. Embora convencionalmente se aceite que foram os pensadores modernos aqueles que criaram esse expediente político, alguns autores são tentados a atribuir a Platão a sua criação. A ideia que sustenta a defesa de Cícero como fundador do estado de direito repousa na evidência conceitual de que o Arpinate oferece, pela primeira vez na história, uma formulação jurídica cabal do Estado, de acordo com a qual a civitas não é senão a iuris societas, uma associação humana posta sob o império da lei. Nesse sentido, o magistrado que exerce seu poder político e governo o povo, o faz com o respaldo do direito e submetido a ele. Cf. MARTINEZ, Libertas Populi Romani, p. 187. Ora, esse é o sentido da afirmação segunda a qual "o poder do magistrado consiste em governar com decretos justos e úteis conforme as leis. Assim, como as leis governam os magistrados, os magistrados governam o povo; e com razão se diz que o magistrado é a lei que fala, a lei é o magistrado mudo." Cf. CÍCERO, DL III, 2, p. 102.
}

ÁGORA FILOSÓFICA

.v. 1.n. 2 (2014), pp.144-189 e-ISSN 1982-999x 
estabelecida por aqueles que pertencem ao mesmo Estado a fim de que obtenham o que é o seu. Assim, a aequitas é aquilo que, em circunstâncias iguais, reclama tratamento jurídico paria iura. A certeza, por sua vez, é a capacidade que tem o direito de permitir aos seus cidadãos prever, com segurança, o comportamento que, em relação às suas ações, terão seus concidadãos e os órgãos do Estado, pois, onde o direito se ausenta, tudo fica incerto. Ora, por meio dessa propriedade se entende o compromisso da garantia da liberdade por parte do direito. $^{102}$

Salgado indica, na distinção entre libertas civium e libertas populi, outros princípios jurídicos, importantes na prática contemporânea, que, ao tempo e pelo Cícero eram não apenas conhecidos, mas respeitados. Segundo esse autor, a concepção de libertas de Cícero, como concepção romana de liberdade, é a liberdade jurídica, não estóica, mas externa, criada a partir de três fundamentais institutos jurídicos, que são: i) o direito de propriedade privada; ii) livre-arbítrio, entendido como liberdade para decisão e celebração de contratos; e iii) o habeas corpus, cuja origem é interdictum de homine libero exhibendi. ${ }^{103}$ Inobstante essas questões mais práticas do direito, é inegável a influência do Arpinate na cultura ocidental, seja por conta do reconhecimento que, entre os antigos e medievais, gozou sua teoria do direito, seja por conta dos valores literários, argúcia, clareza e perspicácia com que desenvolvia seus argumentos, dado esse que fez dele referência impar no

\footnotetext{
${ }^{102}$ FASSÒ, História de la Filosofia del Derecho - Antiguidad y Edad Media, 99.

${ }^{103}$ SALGADO, O Humanismo de Cícero: a Unidade da Filosofia e da Vida Política e Jurídica, 171. 
pensamento moderno e nos estudiosos do helenismo. A figura de Cícero não pode cair nos ostracismo teórico e merece, sempre mais, leitura e interpretação.

\section{Conclusão}

Com o novo despertar da doutrina do direito natural, é absolutamente comum que as bases clássicas dessa doutrina sejam revistas para serem defendidas ou fustigadas em suas falhas e ingenuidades. Como procurou-se mostrar, acastelando a defesa da base clássica, é possível sugerir, na linha de pensadores como Strauss, Holton, entre outros, que a teoria da lei natural de Cícero é muito mais do que meras reproduções de caráter estoico. Nesse sentido, ela tem mais afinidades teóricas e conceituais como aquela que Aristóteles legou a seus pósteros.

De forma geral e bem suscintamente, defendeu-se que a doutrina do direito natural encontrada em Cícero apresenta a lei natural numa base teórica em que a ideia de natureza é mais próxima daquela que Aristóteles desenvolveu. Com isso, afirmou-se que, inerentes aos poderes da razão, pode-se compreender, nos comandos que endereça ao apetite, a lei natural. Mesmo as remissões à lei eterna, cuja figura Cícero antecipa aos medievais, à Deus, dentro disse contexto teórico, são enfraquecidas porque secundárias em relação a esta ideia de natureza.

Uma vez que a base aristotélica tenha sido evidenciada, procurou-se, a partir das declaração de que o direito se sustenta na natureza, apresentar ideias que modelariam a relação entre direito e justiça na res publica. O direito, como consensus iuris, 
afirmaria a ordem social, res publica, em torno da qual um populus estaria reunido sob o direito. Ora, uma sociedade justa é aquela em que a justiça e o direito se entrelaçam porque ambos oriundos de uma mesma natureza. E sendo esta comunicada à recta ratio, então, claro ficaria que, ante o direito que se apresenta à razão, todas as ordens jurídicas particulares seriam avaliadas porque só é valoroso se for justo e, para sê-lo, é preciso que um critério superior àquele dos estados particulares; e este só é encontrável na natureza que está contida na razão. Ora, visto assim em sua fonte, o direito é a lei da justiça, pois é ela que dá o direito ao liame político. ${ }^{104}$

\section{Referências Bibliográficas}

ANNAS, Julia. Plato's Laws and Cicero's De Legibus. Conference on Philosophy in the $1^{\text {st }}$ Century BC, June 2009.

ARISTÓTELES. Física. Introducción, traducción y notas de Guillermo R. de Echandía. Madrid: Editorial Gredos, 1995. Ética a Nicômaco. Tradução de Leonel Vallandro e Gerd Bornheim da versão inglesa de W.D. Ross. (Coleção Os Pensadores). São Paulo: Abril Cultural, 1984.

. Retórica. Tradução e notas de Manuel Alexandre Júnior, Paulo Farmhouse Alberto e Abel do Nascimento Pena. $2^{\mathrm{a}}$ ed. Lisboa: INCM, 2005.

CÍCERO, Marco Túlio. De Legibus. Disponível em: http://www.thelatinlibrary.com/cicero/leg.shtml, acessado em 14/10/2012.

Las Leyes. Traducción, introducción y notas por A.

D’Ors. Madrid: Instituto de Estudios Políticos, 1953.

. Das Leis. Introdução, tradução e notas por Marino Kury. Caxias do Sul: Educs, 2004.

De Re Publica. Disponível em: http://www.thelatinlibrary.com/cicero/repub.shtml, acessado em 14/10/2012.

. Da Republica. Tradução e notas por Amador Cisneiro. $2^{\mathrm{a}}$ ed. São Paulo: Edipro, 2011.

\footnotetext{
${ }^{104}$ VALENTE, A Ética Estóica em Cícero, 304.

ÁGORA FILOSÓFICA

.v. 1.n. 2 (2014), pp.144-189 e-ISSN 1982-999x
} 
Da Republica. Tradução Amador Cisneiro. (Coleção Os Pensadores). São Paulo: Abril Cultural, 1985.

De Officiis. Disponível em:

http://www.thelatinlibrary.com/cicero/off.shtml, acessado em 14/10/12.

Dos Deveres. Tradução, introdução, notas, índice e glossário por Carlos Humberto Gomes. Lisboa: Edições 70, 2000.

De Finibus Bonorum et Malorum. trans. H. Rackham. London: William Heinemann/Loeb Classical Library, 1951. (Disponível em: http://s3.amazonaws.com/loebolus/L040.pdf, acessado em 27/02/13).

COLlINS, W. Lucas. Cicero: Ancient Classics for English Readers. Teddington, Middlesex: The Echo Library, 2007.

FASSÒ, Guido. História de la Filosofia del Derecho Antiguedad y Edad Media. $3^{\mathrm{a}}$ ed. Madrid: Ediciones Pirámide, 1982.

FINNIS, John. Lei Natural e Direitos Naturais. São Leopoldo: Unisinos, 2007.

FOX , Matthew.Cicero's Philosophy of History. Oxford: Oxford University Press, 2007.

HARRIES, Jill. Cicero and Law. In: POWELL, Jonathan; PATERSON, Jeremy. (Orgs.) Cicero, the Advocate. Oxford: Oxford University Press, 2004.

JAEGER, Werner. Alabanza de la Ley. Los Orígenes de la Filosofía Del Derecho y los Griegos. Madrid: Instituto de Estudíos Políticos, 1953.

LACERDA, Bruno A. Direito Natural em Platão - As Origens Gregas da Teoria Jusnaturalista. Curitiba: Juruá Editora, 2009.

MARTINEZ, Jesús D. “Libertas Populi Romani” (Libertad política, historia y derecho natural en Cicerón). Revista de Estudios Políticos, n 208-209, pp. 163-194, 1978.

NICGORSKI, Walter J. Cicero and The Natural Law. Disponível em: http://www.nlnrac.org/classical/cicero, acessado em 03/07/11.

Cicero and the Rebirth of Political Philosophy, The

Political Science Reviewer, n. 8, p. 63-10, Fall, 1978.

- Cicero's paradoxes and his idea of utility. Political

Theory, n. 12, 4, p. 557-578, 1984.

PAWELL, J. C. Introduction: Cicero's Philosophical Works and Their Backgraund. In: PAWELL, J. C. (Org.) Cicero, The Philosopher - Twelve Papers. Oxford: Clarenton Press, 1999. 
PIZZORNI, Reginaldo. Il Diritto Naturale - dalle origini a $S$ Tomamaso d'Aquino. Bologna: Edizioni Studio Domenicano, 2000.

ROCHA PEREIRA, Maria Helena. Introdução. In: PLATÃO. A República. $9^{a}$ ed. Lisboa: Fundação Calouste Gulbbenkian, 2001.

ROHLING, Marcos. Lei Natural e Direito. A Crítica de Finnis ao Positivismo Jurídico. Ethic@ (UFSC), v. 11, p. 159-182, 2012.

ROSS, David. Aristóteles. Trad. Luís Filipe Bragança Teixeira. Lisboa: Dom Quixote, 1987.

SALGADO, Carlos J. O Humanismo de Cícero: a Unidade da Filosofia e Vida Política e Jurídica. Revista Brasileira de Estudos Políticos [Série "Estudos Sociais e Políticos" - Edição Comemorativa dos 120 anos da Faculdade de Direito da UFMG (1892 - 2012)], no 40, p. 157-176, 2012.

SEAGRAVE, Steve A. Cicero, Aquinas, and Contemporary Issues in Natural Law Theory. The Review of Metaphysics, vol. 62, No. 3, March, 2009.

STORCK, Alfredo. Direito Subjetivo e Propriedade. Sobre o Tomismo de Villey. Dois Pontos, Curitiba, São Carlos, vol. 7, n. 2, p.47-72, outubro, 2010.

TORRE, A. S. Los Griegos y el Derecho Natural. Madrid: Editorial Tecnos, 1962.

VALENTE, Milton. A Ética Estóica em Cícero. Caxias do Sul: Educs, 1984.

VILLEY, Michel. A Formação do Pensamento Jurídico Moderno. São Paulo: Martins Fontes, 2005.

WOOD, Neal. Cicero's Social and Political Thought. Berkeley and Los Angeles: University of California Press, 1991. 